\title{
Growth Temperature-dependent Variation in the Bacteriophage-inactivating Capacity and Antigenicity of Yersinia enterocolitica Lipopolysaccharide
}

\author{
By YOSHIHIRO KAWAOKA, * KOICHI OTSUKI AND \\ MISAO TSUBOKURA \\ Department of Veterinary Microbiology, Faculty of Agriculture, Tottori University, Tottori-shi, \\ Tottori 680, Japan
}

(Received 30 November 1982; revised 25 March 1983)

\begin{abstract}
Growth temperature affected the structure of Yersinia enterocolitica Ye 3827 lipopolysaccharide (LPS). Although $Y$. enterocolitica Ye 3827 synthesized smooth LPS when grown at a low temperature $\left(25^{\circ} \mathrm{C}\right)$, partial smooth-rough transition occurred when the bacteria were grown at the physiological temperature $\left(37^{\circ} \mathrm{C}\right)$. The structural alteration was detected by bacteriophageinactivation assay and chemical and immunological analyses. LPS prepared from bacteria grown at $25^{\circ} \mathrm{C}$ inactivated a number of bacteriophages that recognize the $\mathrm{O}$-antigenic polysaccharide portion of LPS, whereas more than 3000 times the amount of LPS from bacteria grown at $37^{\circ} \mathrm{C}$ was required for the same degree of inactivation. The antigenic determinant(s) responsible for the major reaction between $25^{\circ} \mathrm{C}$-LPS and anti- $25^{\circ} \mathrm{C}$-bacteria was located on the O-antigenic polysaccharide portion of LPS, but those responsible for the major reaction between $37^{\circ} \mathrm{C}$-LPS and anti-37 ${ }^{\circ} \mathrm{C}$-bacteria were located on the R-core or inner portion of LPS.
\end{abstract}

\section{INTRODUCTION}

Yersinia enterocolitica infection causes a variety of syndromes in man: acute gastroenteritis and other forms of abdominal illness, arthritis, and erythema nodosum. Although this organism grows at an unusually broad range of temperature (Maruyama, 1973), the bacteria grown at $25^{\circ} \mathrm{C}$ and those grown at $37^{\circ} \mathrm{C}$ are quite different in biological and biochemical characteristics. For example, bacteria grown at $25^{\circ} \mathrm{C}$ show bacteriophage sensitivity (Mollaret \& Nicolle, 1965), adherence to mammalian epithelial cell lines (Okamoto et al., 1980), motility (Schleifstein \& Coleman, 1939), and indirect haemolysin (Tsubokura et al., 1979) and enterotoxin (Pai \& Mors, 1978) production which those grown at $37^{\circ} \mathrm{C}$ do not show.

In previous reports, we have shown that the insensitivity of the bacteria grown at $37^{\circ} \mathrm{C}$ to bacteriophages I, IV, VIII, and XI correlated with a smaller amount of bacteriophage receptors on the cell surface of the $37^{\circ} \mathrm{C}$-grown bacteria than of the $25^{\circ} \mathrm{C}$-grown bacteria (Kawaoka et al., $1982 b, c)$. The bacteriophage XI receptor was partially purified and seemed to be a glycoconjugate other than lipopolysaccharide (LPS). The receptor molecule was synthesized at $25^{\circ} \mathrm{C}$ but not at $37^{\circ} \mathrm{C}$ (Kawaoka et al., 1982c). Thus, we have shown a growth temperaturedependent structural alteration of a cell-surface component by bacteriophage-inactivation assay.

Acker et al. (1980) found a growth temperature-dependent difference in thickness of the outer membrane of $Y$. enterocolitica and examined LPS preparations from the bacteria grown at different temperatures. They showed that LPS from cells grown at higher temperatures had a reduced content of an O-specific sugar, 6-deoxy-L-altrose (Acker et al., 1980). They also reported

\footnotetext{
Abbreviations: LPS, lipopolysaccharide; O-PS, O antigenic polysaccharide; PCP-LPS, LPS prepared by the phenol-chloroform-petroleum ether method; PW-LPS, LPS prepared by the phenol water method; KDO, 2-keto3-deoxyoctonate.
} 
that smooth bacteria grown at $40{ }^{\circ} \mathrm{C}$ resembled rough bacteria grown at $22^{\circ} \mathrm{C}$ in their reactivity with antibody to the enterobacterial common antigen (Acker et al., 1981).

In the present paper, we show a growth temperature-dependent variation in the bacteriophage-inactivating capacity of LPS and examine the structure and antigenicity of purified LPS from organisms grown at different temperatures.

\section{METHODS}

Bacteria and bacteriophages. Yersinia enterocolitica strain Ye 3827 (biovar 4, serovar $\mathrm{O}: 3$ ) and phages I through IX used routinely for phage typing of $Y$. enterocolitica were obtained from Dr H. H. Mollaret (National Centre of Yersinia, Pasteur Institute, Paris, France).

A bacteriophage IV-resistant strain was isolated after spotting drops of a high-titre bacteriophage suspension on freshly prepared lawns of strain Ye 3827 . After incubation for $48 \mathrm{~h}$ at $25^{\circ} \mathrm{C}$, colonies growing within the lytic areas were picked and streaked on to nutrient agar plates. The isolated colonies were further tested for sensitivity to the homologous bacteriophage.

Bacteriophages were propagated on Y. enterocolitica Ye 3827 in nutrient broth, and the lysates were used without further purification.

Medium. Bacteria were cultivated on nutrient agar plates ( $\mathrm{pH} 7 \cdot 2$ ). No supplementation with any exogenous cation was made.

Antisera. Antisera to smooth bacteria, Ye 3827 , grown at $25^{\circ} \mathrm{C}\left(25^{\circ} \mathrm{C}\right.$-bacteria $)$ or at $37^{\circ} \mathrm{C}\left(37^{\circ} \mathrm{C}\right.$-bacteria $)$ and to rough bacteria, Ye 3827 IV-3, grown at $25^{\circ} \mathrm{C}$ (R-bacteria) were prepared with heat-killed bacteria. Rabbits were immunized intravenously four times at intervals of $7 \mathrm{~d}$. Rabbits were bled $7 \mathrm{~d}$ after the last injection.

Extraction of LPS. Bacteria were grown on nutrient agar plates for $48 \mathrm{~h}$. LPS from $25^{\circ} \mathrm{C}$-bacteria $\left(25^{\circ} \mathrm{C}\right.$-LPS) and $37^{\circ} \mathrm{C}$-bacteria $\left(37^{\circ} \mathrm{C}\right.$-LPS) was obtained by the hot aqueous phenol method of Westphal \& Jann (1965). LPS from R-bacteria (R-LPS) was obtained by the phenol-chloroform-petroleum ether (PCP) method of Galanos et at. (1969). Since the yield of LPS was very low by the PCP method, a second extraction was made by the hot aqueous phenol method of Westphal \& Jann (1965). LPS was purified by repeated sedimentation in a preparative ultracentrifuge.

Column chromatographic analysis of acetic acid hydrolysed LPS. LPS in an amount of $100 \mathrm{mg}$ was partially hydrolysed with $1 \%$ acetic acid at $100^{\circ} \mathrm{C}$ for $1.5 \mathrm{~h}$ (Davies $e t$ al., 1955). The hydrolysate was neutralized with sodium hydroxide and centrifuged at $3000 \mathrm{~g}$ for $30 \mathrm{~min}$. The supernatant was concentrated by evaporation under vacuum. The concentrate was applied on a Sephadex G-50 column $(1.2 \times 111 \mathrm{~cm})$ and eluted with pyridine acetate buffer (pH 5.4) containing $10 \mathrm{ml}$ pyridine and $4 \mathrm{ml}$ acetic acid in 11 distilled water at a flow rate of $6 \mathrm{ml} \mathrm{h}^{-1}$. The effluent was collected in $3 \mathrm{ml}$ fractions, which were each analysed for neutral sugar (Dubois et al., 1956).

Bacteriophage-inactivation assay. Bacteriophage-inactivation assay was performed as reported previously (Kawaoka et al., 1982c). A $0 \cdot 1 \mathrm{ml}$ portion of a suspension of bacteriophage ( $10^{3}$ p.f.u.) was incubated with the same volume of LPS for $1 \mathrm{~h}$ at $25^{\circ} \mathrm{C}$. Free p.f.u. were determined by plating on nutrient agar plates with $\mathrm{Ye} 3827$ cells.

Immunological methods. Double immunodiffusion tests in $1 \%(\mathrm{w} / \mathrm{v})$ agarose gel were performed as described previously (Kawaoka et al., 1979). Each antigen was dissolved in phosphate-buffered saline containing $0 \cdot 1 \%(\mathrm{w} / \mathrm{v})$ sodium taurocholate.

In immunodiffusion inhibition tests, an antiserum $(30 \mu \mathrm{l})$ was incubated with an inhibitor for $3 \mathrm{~h}$ at $37^{\circ} \mathrm{C}$.

Passive haemagglutination inhibition (HI) tests were performed according to Lindberg \& Hellerqvist (1980) with sheep erythrocytes sensitized with LPS. Agglutination was read after incubation for $1 \mathrm{~h}$ at $37^{\circ} \mathrm{C}$ and after an additional $18 \mathrm{~h}$ in the cold.

Chemical analyses. Neutral sugar and phosphorus were determined by the methods of Dubois et al. (1956) and Ames et al. (1960). Protein was estimated by the Lowry method. Amino groups and 2-keto-3-deoxy-octonate were determined by the 2,4,6,trinitrobenzenesulphonic acid method of Goldfarb (1966) and the thiobarbituric acid method of Weissbach \& Hurwitz (1959), respectively. Fatty acid was determined as methyl esters with docosanoic acid as an internal standard by GLC as described previously (Tsuji et al., 1981). Sugar was determined as trimethylsilyl derivatives by GLC as described previously (Kawaoka et al., 1982a). Briefly, samples and standard monosaccharides containing 100 to $200 \mu \mathrm{g}$ carbohydrate and $10 \mu \mathrm{g}$ mannitol as an internal standard were hydrolysed with $5 \%(\mathrm{v} / \mathrm{v})$ hydrochloric acid/methanol at $80^{\circ} \mathrm{C}$ for $18 \mathrm{~h}$. Each trimethylsilylated sugar derivative was analysed in a glass column $(4 \times 2000 \mathrm{~mm})$ of $2 \%$ OV-1 on Chromosorb W $(60 / 80 \mathrm{mesh})$. O-PS of $Y$. enterocolitica strain Ye 128 (serotype $\mathrm{O}: 2, \mathrm{O}: 3$ ), being a homopolymer composed of $(1 \rightarrow 2$ )-linked 6-deoxy- $\beta$-Laltropyranosyl residue (Hoffman et al., 1980), was hydrolysed completely with $0.5 \mathrm{M}$-sulphuric acid for $16 \mathrm{~h}$ at $100^{\circ} \mathrm{C}$. The hydrolysed material was purified by paper chromatography, and the purified material was used as standard 6-deoxy-L-altrose. A gas chromatography apparatus, GC-8A (Shimazu Seisakusho, Kyoto) was used for the analyses. 
Table 1. Bacteriophage inactivation with LPS prepared from Ye 3827 cells grown at $25^{\circ} \mathrm{C}$ and $37^{\circ} \mathrm{C}$

LPS was assayed for receptor activity as described in the text.

\begin{tabular}{lcr} 
& \multicolumn{2}{c}{$\begin{array}{c}50 \% \text { inactivation dose }(\mu \mathrm{g}) \text { of } \\
\text { LPS prepared from the cells } \\
\text { Prown at: }\end{array}$} \\
\cline { 2 - 3 } Phage & $25^{\circ} \mathrm{C}$ & $37{ }^{\circ} \mathrm{C}$ \\
I & 0.0076 & $>100$ \\
II & 0.32 & $>100$ \\
III & 0.01 & 90 \\
IV & 0.004 & 14 \\
V & 65 & $>100$ \\
VI & 0.0025 & 29 \\
VII & 0.01 & 30 \\
VIII & 0.4 & $>100$ \\
IX & 0.5 & $>100$
\end{tabular}

Table 2. Chemical composition of LPS and its derivatives prepared from different sources

Except where indicated the values are expressed as percentage (dry weight) of LPS.

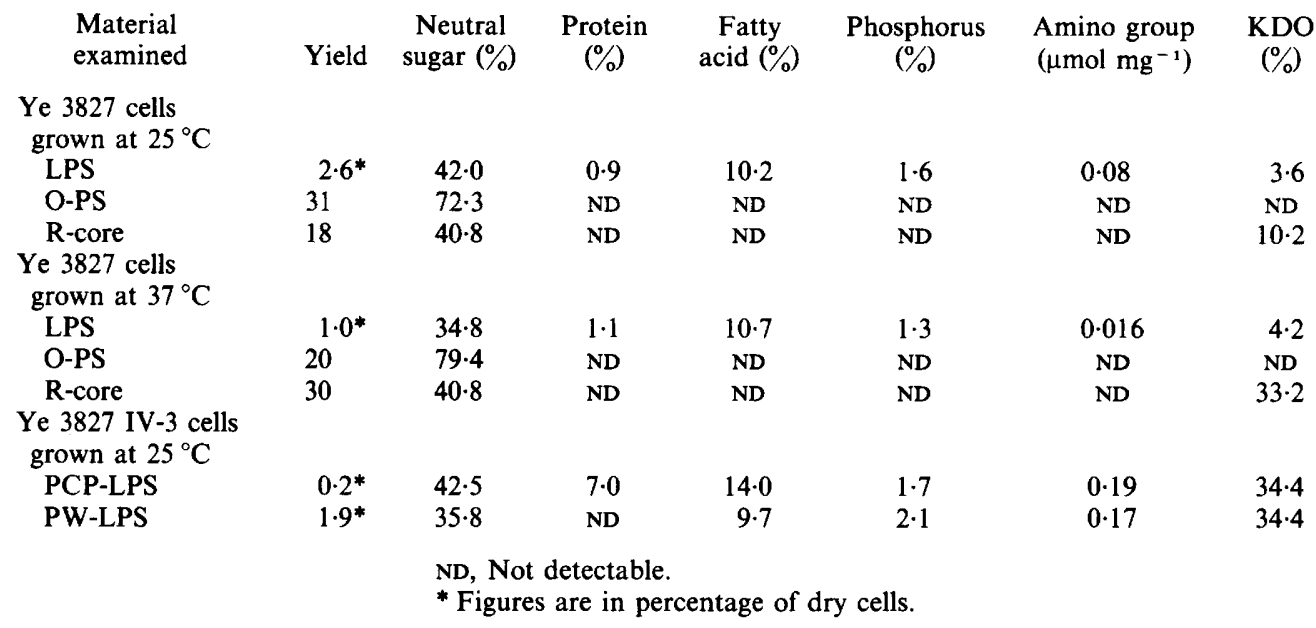

\section{RESULTS}

Growth temperature-dependent variation in the bacteriophage-inactivating capacity of LPS

Bacteriophages II, III, V, VI, VII, and IX adsorbed to $25^{\circ} \mathrm{C}$-bacteria but not $37^{\circ} \mathrm{C}$-bacteria, as had previously been shown for the phages I, IV, VIII, and XI (Kawaoka et al., 1982b,c). The receptor(s) for phages I through IX is located on the LPS (Table 1). $25^{\circ} \mathrm{C}$-LPS inactivated phages I through IX more efficiently than did $37^{\circ} \mathrm{C}$-LPS (Table 1 ). $25^{\circ} \mathrm{C}$-LPS required for $50 \%$ phage inactivation of all these phages except phage $V$ was $0.5 \mu \mathrm{g}$ or less, whereas more than 3000 times as much of $37^{\circ} \mathrm{C}$-LPS was required for the same degree of inactivation.

A spontaneous mutant resistant to phage IV was isolated from strain Ye 3827. The resistant strain, Ye 3827 IV-3, did not adsorb phage IV nor was it agglutinable in slide tests with a 1:10 dilution of the antiserum to $25^{\circ} \mathrm{C}$-bacteria. The strain appeared to be a rough mutant. Although the PCP method was applied, the yield of Ye 3827 IV-3 LPS was very low (Table 2). Cell residue was subsequently extracted with phenol-water. The yield of LPS by the phenol-water method was similar to that of other enterobacterial LPS (Table 2). Neither LPS preparation inactivated any of the bacteriophages. 
Table 3. Sugar composition of LPS and its derivatives prepared from different sources

The results are expressed as a molar ratio to heptose.

\begin{tabular}{|c|c|c|c|c|c|c|}
\hline Material examined & 6-Deoxy-L-altrose & Rhamnose & Galactose & Glucose & Heptose & Glucosamine \\
\hline \multicolumn{7}{|l|}{$\begin{array}{l}\text { Ye } 3827 \text { cells } \\
\text { grown at } 25^{\circ} \mathrm{C}\end{array}$} \\
\hline LPS & $2 \cdot 20$ & $0 \cdot 28$ & $0 \cdot 21$ & 0.84 & $1 \cdot 00$ & 0.26 \\
\hline O-PS & $11 \cdot 60$ & 1.50 & $0 \cdot 23$ & 0.56 & 1.00 & ND \\
\hline R-core & ND & ND & $0 \cdot 35$ & 0.90 & 1.00 & ND \\
\hline \multicolumn{7}{|l|}{$\begin{array}{l}\text { Ye } 3827 \text { cells } \\
\text { grown at } 37^{\circ} \mathrm{C}\end{array}$} \\
\hline LPS & $1 \cdot 24$ & $0 \cdot 13$ & $0 \cdot 25$ & 0.79 & 1.00 & $0 \cdot 26$ \\
\hline O-PS & $9 \cdot 10$ & $1 \cdot 20$ & 0.23 & 0.63 & 1.00 & ND \\
\hline R-core & ND & ND & 0.26 & 0.47 & 1.00 & ND \\
\hline \multicolumn{7}{|l|}{$\begin{array}{l}\text { Ye } 3827 \text { IV-3 cells } \\
\text { grown at } 25^{\circ} \mathrm{C}\end{array}$} \\
\hline PCP-LPS & ND & ND & $0 \cdot 33$ & 0.90 & $1 \cdot 00$ & $0 \cdot 28$ \\
\hline PW-LPS & ND & ND & 0.26 & 0.49 & 1.00 & $0 \cdot 30$ \\
\hline
\end{tabular}

ND, Not detectable.

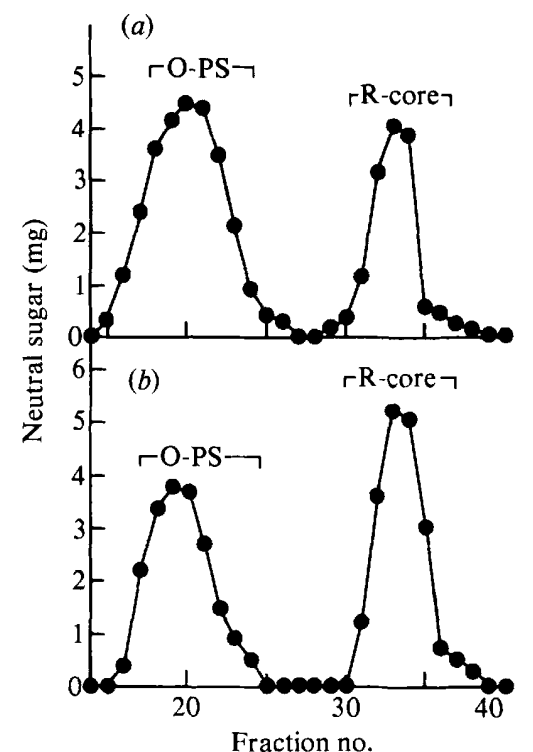

Fig. 1. Sephadex G-50 gel filtration of acetic acid-hydrolysed LPS prepared from Ye 3827 cells grown at $25^{\circ} \mathrm{C}(a)$ or $37^{\circ} \mathrm{C}(b)$. Each fraction was analysed for neutral sugar by the method described in the text. Blue dextran was eluted at fraction 14.

\section{Chemical composition of LPS}

$25^{\circ} \mathrm{C}$ - and $37^{\circ} \mathrm{C}$-LPS were compared in their chemical properties. As reported previously with $Y$. enterocolitica O:3 LPS (Ellwood \& Kirk, 1971), 6-deoxy-L-altrose was found in both (Table 3). The 2-keto-3-deoxyoctonate contents and the ratio of glucose to heptose were almost the same in each (Tables 2 and 3). However, the ratio of 6-deoxy-L-altrose to heptose in $37^{\circ} \mathrm{C}$ LPS was much lower than that in $25^{\circ} \mathrm{C}$-LPS, as reported previously (Acker et al., 1980). Another difference was in the amount of free amino groups. The $25^{\circ} \mathrm{C}$-LPS molecule contained five times as many amino groups as $37^{\circ} \mathrm{C}$-LPS (Table 2).

To investigate the polysaccharide portions of LPS, we hydrolysed LPS preparations with dilute acetic acid. Hydrolysed materials prepared from $25^{\circ} \mathrm{C}$ - and $37^{\circ} \mathrm{C}$-LPS were fractionated on a Sephadex G-50 column into O-PS fractions and R-core fractions (Fig. 1).

The yield of O-PS was higher than that of R-core in $25^{\circ} \mathrm{C}$-LPS and lower in $37^{\circ} \mathrm{C}$-LPS (Table 2). Sugar compositions of the O-PS preparations were very similar and consisted mainly of 6deoxy-L-altrose. 

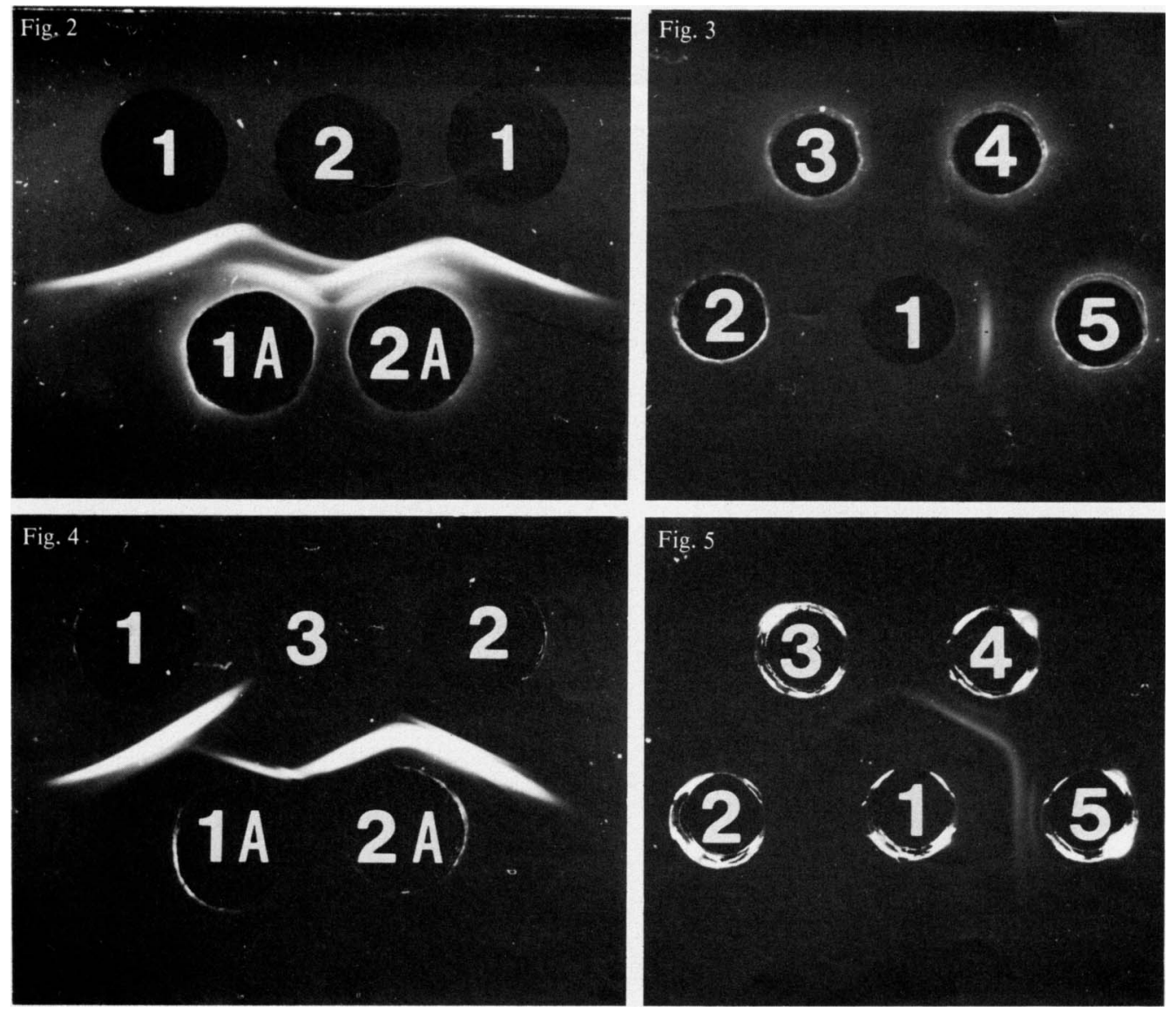

Fig. 2. Immunodiffusion in agarose gel of antiserum against $\mathrm{Ye} 3827$ cells grown at $25^{\circ} \mathrm{C}(1 \mathrm{~A})$ and $37^{\circ} \mathrm{C} \mathrm{(2A)}$ with LPS prepared from Ye 3827 cells grown at $25^{\circ} \mathrm{C}(1)$ and $37^{\circ} \mathrm{C}(2)$. Each antigen was dissolved at $3 \mathrm{mg} \mathrm{ml}^{-1}$.

Fig. 3. Immunodiffusion inhibition test in agarose gel of antiserum against Ye 3827 cells grown at $25^{\circ} \mathrm{C}$ with LPS ( $3 \mathrm{mg} \mathrm{ml}^{-1}$ ) prepared from Ye 3827 cells grown at $25^{\circ} \mathrm{C}$ (1). Antiserum $(30 \mu 1)$ was preincubated for $3 \mathrm{~h}$ at $37^{\circ} \mathrm{C}$ with $3(2), 0 \cdot 3(3), 0.03$ (4), and $0(5) \mathrm{mg}$ of O-PS from the $25^{\circ} \mathrm{C}$-LPS preparation, before being added to the wells.

Fig. 4. Immunodiffusion in agarose gel of antiserum against $\mathrm{Ye} 3827$ cells grown at $25^{\circ} \mathrm{C}$ (l A) and $37^{\circ} \mathrm{C} \mathrm{(2A)} \mathrm{with} \mathrm{LPS} \mathrm{prepared} \mathrm{from} \mathrm{Ye} 3827$ cells grown at $25^{\circ} \mathrm{C}(1)$ and $37^{\circ} \mathrm{C}(2)$ and from Ye $3827 \mathrm{IV}$ 3 cells grown at $25^{\circ} \mathrm{C}(3)$ (R-LPS). Each antigen was dissolved at $3 \mathrm{mg} \mathrm{ml}^{-1}$.

Fig. 5. Immunodiffusion inhibition test in agarose gel of antiserum against Ye 3827 cells grown at $37^{\circ} \mathrm{C}$ with LPS $\left(3 \mathrm{mg} \mathrm{mi}^{-1}\right)$ prepared from Ye 3827 cells grown at $37^{\circ} \mathrm{C}(1)$. Antiserum $(30 \mu \mathrm{l})$ was preincubated for $3 \mathrm{~h}$ at $37^{\circ} \mathrm{C}$ with $100(2), 10(3), 1$ (4), and $0(5) \mu \mathrm{g}$ R-LPS, before addition to the wells.

The LPS preparations from the phage-resistant strain (Ye 3827 IV-3) grown at $25^{\circ} \mathrm{C}$ obtained by the different methods were somewhat different in composition. However, the most prominent difference in comparison with the parent LPS was that the preparations from the phage-resistant cells did not contain 6-deoxy-L-altrose or rhamnose (Table 3). Thus, the phageresistant strain, Ye 3827 IV-3, was a rough mutant.

\section{Growth temperature-dependent antigenic variation}

In immunodiffusion tests, the major antigenic determinants were shared by both $25^{\circ} \mathrm{C}$ - and $37^{\circ} \mathrm{C}$-LPS (but their amount was different) (Fig. 2). The major reaction between $25^{\circ} \mathrm{C}$-LPS and anti- $25^{\circ} \mathrm{C}$-bacteria was inhibited by O-PS (Fig. 3) but not by R-LPS from Ye 3827 IV-3 (data 


\section{Table 4. Passive HI tests with LPS prepared from various sources}

Passive HI tests were performed in the micro-HI system using sheep erythrocytes sensitized with LPS. The inhibitor $(25 \mu 1)$ was preincubated with the antiserum $(25 \mu 1)$ containing 4 haemagglutination units for $3 \mathrm{~h}$ at $37^{\circ} \mathrm{C}$, and then a $0.5 \%$ erythrocyte suspension $(50 \mu \mathrm{l})$ was added to the reaction mixture.

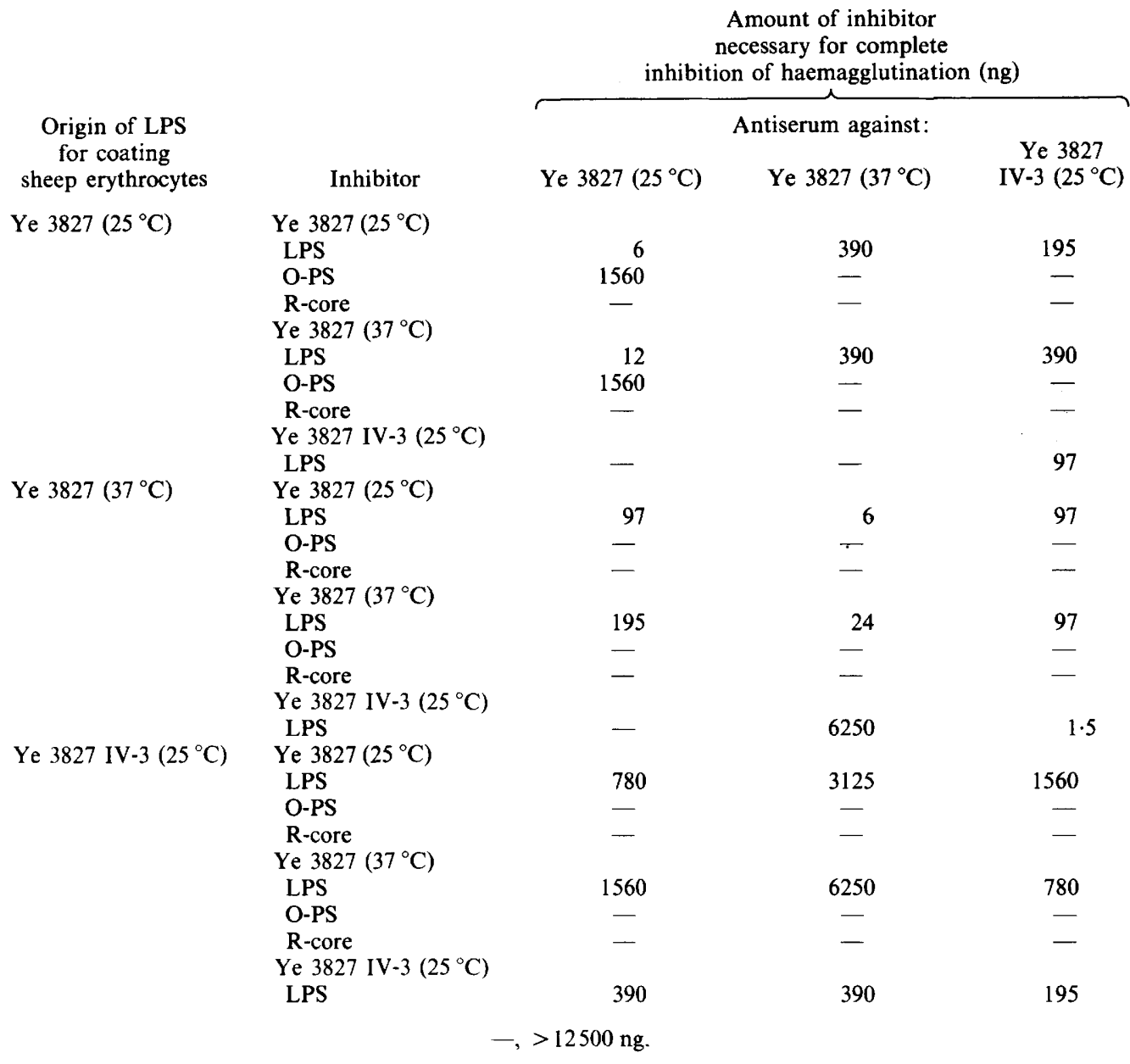

not shown). R-LPS gave a line against the antiserum to $25^{\circ} \mathrm{C}$-bacteria that fused with the minor line between this antiserum and $25^{\circ} \mathrm{C}$-LPS (Fig. 4). Against antiserum to $37^{\circ} \mathrm{C}$-bacteria, R-LPS gave a line that fused with the major line formed between this antiserum and $37^{\circ} \mathrm{C}$-LPS (Fig. 4). The major portion of the major reaction in $37^{\circ} \mathrm{C}$-LPS was inhibited by R-LPS (Fig. 5) but not by O-PS from either $37^{\circ} \mathrm{C}$ - or $25^{\circ} \mathrm{C}$-LPS (data not shown). Both LPS preparations from R-bacteria showed the same reaction irrespective of the method they were prepared.

The antigenic variation of LPS was further examined by the HI test in the LPS/homologous or heterologous anti-bacterial serum system (Table 4). Both O-PS from the $25^{\circ} \mathrm{C}$ - and $37^{\circ} \mathrm{C}$-LPS preparations inhibited only the reaction between $25^{\circ} \mathrm{C}$-LPS and the homologous antiserum with the same inhibitory activity $(1.56 \mu \mathrm{g}$ of the polysaccharide was required), indicating that the reaction between O-PS and its antibody was the predominant one in the system. This agreed with the results in the immunodiffusion inhibition test. $25^{\circ} \mathrm{C}$ - and $37^{\circ} \mathrm{C}$-LPS inhibited all the reactions. R-LPS was the most potent inhibitor of all reactions between the antiserum to $\mathrm{R}$ bacteria and erythrocytes coated with $25^{\circ} \mathrm{C}$ - or $37^{\circ} \mathrm{C}$-LPS or with the homologous R-LPS (Table 4, the right-hand column). However, it did not inhibit the reaction between the Ye 3827 
LPS preparations and their homologous or heterologous antiserum with the exception of the reaction between $37^{\circ} \mathrm{C}$-LPS and its homologous antiserum. Both R-LPS preparations again behaved similarly. R-core fractions prepared from Ye 3827 LPS preparations did not inhibit any reaction.

\section{DISCUSSION}

A growth temperature-dependent structural alteration of $Y$. enterocolitica Ye 3827 LPS was revealed by bacteriophage-inactivation assay and by immunological and chemical analyses of purified LPS and its derivatives. $37^{\circ} \mathrm{C}$-LPS contained relatively more of the R-core fraction and less of O-PS than did $25^{\circ} \mathrm{C}$-LPS (Fig. 1 and Table 2). Therefore, $25^{\circ} \mathrm{C}$ - and $37^{\circ} \mathrm{C}$-LPS differed in the relative amount of LPS molecules lacking O-PS, indicating a partial transition from smooth to rough when $Y$. enterocolitica was cultivated at $37^{\circ} \mathrm{C}$. This would agree with the indirect observation by Acker et al. (1981) with antibody against the enterobacterial common antigen.

It is, however, difficult to explain the several thousand-fold decrease in the phage inactivation rate observed in $37^{\circ} \mathrm{C}$-LPS on the basis of only partial smooth-rough transition. The tremendous drop in phage sensitivity suggests that a qualitative change took place in LPS. Such qualitative change would most probably be located on the O-PS portion, because a rough mutant and its LPS were totally devoid of bacteriophage-inactivating capacity. However, O-PS prepared from $25^{\circ} \mathrm{C}$ - and $37^{\circ} \mathrm{C}$-LPS by hydrolysis with dilute acetic acid were similar in their inhibitory activity in the HI tests (Table 4), in their composition (Tables 2 and 3), and in the amount of periodate consumed in periodate oxidation (unpublished data). However, the drastic decrease in the HI potency when comparing O-PS to the homologous LPS (Table 4), suggests that acid-labile determinant(s), destroyed during hydrolysis with acetic acid, may be located on the O-PS portion. As alkaline treatment somewhat altered the reactivity of $25^{\circ} \mathrm{C}$-LPS in the immunodiffusion test (unpublished observation), the determinant might be a substituent such as an O-acetyl group. Therefore, acid-labile determinant(s) might be involved in the qualitative change in LPS responsible for the change in bacteriophage sensitivity.

The antigenic determinant(s) responsible for the major precipitin line between $25^{\circ} \mathrm{C}$-LPS and anti- $25^{\circ} \mathrm{C}$-bacteria seems to be located on the O-PS portion since (i) this line was not found with R-LPS (Fig. 4), (ii) $37^{\circ} \mathrm{C}$-LPS formed a weaker but identical precipitation line (Fig. 2), and (iii) O-PS inhibited the reaction (Fig. 3). On the other hand, the determinant(s) responsible for the major portion of the major line between $37^{\circ} \mathrm{C}$-LPS and anti-37 ${ }^{\circ} \mathrm{C}$-bacteria seems to be located on R-LPS also, since the precipitation line formed by R-LPS against anti-37 ${ }^{\circ} \mathrm{C}$-bacteria fused with the major line against $37^{\circ} \mathrm{C}$-LPS (Fig. 4) and R-LPS inhibited the major reaction (Fig. 5). However, R-core fractions obtained by mild acid hydrolysis did not show inhibitory activity in HI tests (Table 4) or in immunodiffusion-inhibition tests (data not shown). The reason is uncertain. Acid-labile determinant(s) such as phosphate might be involved, since alkaline treatment altered the reactivities of $\mathrm{R}$ - and $37^{\circ} \mathrm{C}$-LPS in the immunodiffusion tests (unpublished observation).

Immunogenicity of $Y$. enterocolitica cells differed depending on whether the cells were grown at $25^{\circ} \mathrm{C}$ or at $37^{\circ} \mathrm{C}$. The immunodiffusion and $\mathrm{HI}$ tests indicate that the rabbit antiserum against $37^{\circ} \mathrm{C}$-bacteria contained mainly antibody against R-core or inner portion of LPS. The poor anti-O response in rabbits immunized with $37^{\circ} \mathrm{C}$-bacteria can not be explained by the structural difference of isolated LPS. The reduced amount of O-PS in $37^{\circ} \mathrm{C}$-LPS seems not to be a sufficient explanation, because usually O-PS is a better immunogen than R-core. The different immune response might be due to other factors rather than the structural difference in LPS, such as covering up of LPS by capsular-like material.

Structural heterogeneity of LPS is present in smooth Gram-negative bacteria under normal culture conditions (Goldman \& Leive, 1980; Jann et al., 1975; McIntire et al., 1969; Nowotny, 1966). The culture condition also affects the structure (Fromme \& Schlecht, 1973; Nikaido, 1970). McConnell \& Wright (1979) showed that the sensitivity of Salmonella anatum A1 cells to the rough-specific bacteriophage Felix O-1 increased at low growth temperature $\left(20\right.$ to $25^{\circ} \mathrm{C}$ ) due to partial smooth-rough transition occurring at lower temperatures. In $S$. anatum, the 
proportion of LPS molecules substituted with O-PS is larger at $37^{\circ} \mathrm{C}$ than at $25^{\circ} \mathrm{C}$; in $Y$. enterocolitica, the reverse is the case. However, the extent of the structural change, as indicated by chemical analyses, was much higher in $Y$. enterocolitica than in $S$. anatum. Furthermore, a qualitative change in the O-PS portion was suggested by bacteriophage-inactivation assay.

Attempts to elucidate the mechanism of temperature-dependent changes have been made mainly in $Y$. pestis (Darveau et al., 1980; Straley \& Brubaker, 1981, 1982; Zahorchak et al., 1979). Yersinia pestis requires $2.5 \mathrm{mM}-\mathrm{Ca}^{2+}$ for growth at $37^{\circ} \mathrm{C}$ but not at $25^{\circ} \mathrm{C}$. Zahorchak et al. (1979) showed that a shift of cultivation temperature from $26^{\circ} \mathrm{C}$ to $37^{\circ} \mathrm{C}$ in a $\mathrm{Ca}^{2+}$-deficient medium caused termination of net RNA synthesis prior to that of protein synthesis in $Y$. pestis. As distinct from $Y$. pestis, $Y$. enterocolitica can grow at $37^{\circ} \mathrm{C}$, although at lower growth rate than at $25^{\circ} \mathrm{C}$. Therefore, termination of net RNA synthesis observed in $Y$. pestis can not explain the temperature-dependent features in $Y$. enterocolitica. In $Y$. enterocolitica, Portnoy et al. (1981) reported that three major outer membrane polypeptides appeared during growth at $37^{\circ} \mathrm{C}$ but not at $25^{\circ} \mathrm{C}$ and the addition of $2.5 \mathrm{mM}^{-\mathrm{Ca}^{2+}}$ to the growth medium completely repressed the expression of these polypeptides. By contrast, the partial smooth-rough transition described here occurred at $37^{\circ} \mathrm{C}$ regardless of the addition of $\mathrm{Ca}^{2+}$ (unpublished observation). Therefore, there seem to be at least two kinds of temperature dependency; one is related to $\mathrm{Ca}^{2+}$ and the other not.

We thank Dr H. H. Mollaret for providing the bacteriophages and the indicator cell. This work was partly supported by Grant-in-Aid for Scientific Research from the Ministry of Education, Science and Culture, Japan.

\section{REFERENCES}

ACKer, G., Wartenberg, K. \& KNAPP, W. (1980). Zuckerzusammensetzung des Lipopolysaccharids und Feinstruktur der äusseren Membran (Zellwand) bei Yersinia enterocolitica. Zentralblatt für Bakteriologie, Parasitenkunde, Infektionskrankheiten und $\mathrm{Hy}$ giene (Abteilung I, Originale A) 247, 229-240.

ACKer, G., KNAPP, W., WartenberG, K. \& Mayer, H. (1981). Localization of enterobacterial common antigen in Yersinia enterocolitica by the immunoferritin technique. Journal of Bacteriology 147, 602-611.

AmES, B. N. \& DoBIN, D. T. (1960). The role of polyamines in the neutralization of bacteriophage deoxyribonucleic acid. Journal of Biological Chemistry 235, 769-775.

Darveau, R. P., Charnetzky, W. T. \& Hurlbert, R. E. (1980). Outer membrane protein composition of Yersinia pestis at different growth stages and incubation temperatures. Journal of Bacteriology 143, 942-949.

Davies, D. A. L., Morgan, W. T. J. \& Record, B. R. (1955). Studies in immunochemistry. 15. The specific polysaccharide of the dominant ' $O$ ' somatic antigen of Shigella dysenteriae. Biochemical Journal 60, 290-303.

Dubois, C. S., Gilles, K. A., Hamilton, J. K., Rebers, P. A. \& SMITH, F. (1956). Colorimetric method for determination of sugars and related substances. Analytical Chemistry 38, 350-356.

Ellwood, D. C. \& KIRK, G. R. A. (1971). The occurrence of 6-deoxy-L-altrose in the lipopolysaccharide of Yersinia enterocolitica. Biochemical Journal 122, 14.

FROMME, I. \& SCHLECHT, S. (1973). Influence of aeration conditions in fermentation cultures on the chemical composition of Salmonella lipopolysac- charides. Zentralblatt für Bakteriologie, Parasitenkunde, Infektionskrankheiten und Hygiene (Abteilung $I$, Originale A) 224, 331-344.

Galanos, C., Luderritz, O. \& WestPhal, O. (1969). A new method for the extraction of $R$ lipopolysaccharides. European Journal of Biochemistry 9, 245-249.

GOLDFARB, A. R. (1966). A kinetic study of reactions of amino acids and peptides with the TNBS. Biochemistry 5, 2570-2577.

Goldman, R. C. \& Leive, L. (1980). Heterogeneity of antigenic side chain length in lipopolysaccharide from Escherichia coli $\mathrm{O} 111$ and Salmonella typhimurium LT2. European Journal of Biochemistry 107, 145153.

HoffMAN, J., LINDBERG, B. \& BRUBAKER, R. R. (1980). Structural studies of the O-specific side-chains of the lipopolysaccharide from Yersinia enterocolitica Ye 128. Carbohydrate Research 78, 212-214.

JANN, B., RESKE, K. \& JANN, K. (1975). Heterogeneity of lipopolysaccharides. Analysis of polysaccharide chain lengths by sodium dodecylsulfate-polyacrylamide gel electrophoresis. European Journal of Biochemistry 60, 239-246.

KaWaOKa, Y., NaIKI, M. \& Yanagawa, R. (1979). Radioimmunoassay system using a serovar-specific lipopolysaccharide antigen of Leptospira. Journal of Clinical Microbiology 10, 313-316.

KaWAOKA, Y., NAIKI, M. \& Yanagawa, R. (1982a). Isolation of the antigen-active components from leptospiral serovar-specific lipopolysaccharide antigen by mild acid hydrolysis. Japanese Journal of Veterinary Science 44, 473-478.

KAWAOKA, Y., OTSUKI, K. \& TsuboKURA, M. (1982b). Characteristics of Yersinia enterocolitica bacterio- 
phages. Zentralblatt für Bakteriologie, Parasitenkunde, Infektionskrankheiten und Hygiene (Abteilung I, Originale A) 253, 102-109.

KaWAOKa, Y., Otsuki, K. \& TsubokURa, M. (1982c). Temperature-dependent variation in the synthesis of the receptor for Yersinia enterocolitica bacteriophage XI. Zentralblatt für Bakteriologie, Parasitenkunde, Infektionskrankheiten und Hygiene (Abteilung I, Originale A) 253, 364-369.

LindBerg, A. A. \& HellerQvist, C. (1980). Rough mutants of Salmonella typhimurium: immunochemical and structural analysis of lipopolysaccharides from $\mathrm{rfaH}$ mutants. Journal of General Microbiology 116, 25-32.

MARUYAMA, T. (1973). Studies on biological characteristics and pathogenicity of Yersinia enterocolitica. I. Comparison of growth temperature range between $Y$. enterocolitica and other enteropathogenic bacteria. Japanese Journal of Bacteriology (in Japanese) 28, 343-348.

MCConnell, N. \& WRight, A. (1979). Variation in the structure and bacteriophage-inactivating capacity of Salmonella anatum lipopolysaccharide as a function of growth temperature. Journal of Bacteriology 137, 746-751.

McIntire, F. C., Barlow, G. G., Sievert, H. W., FINLEY, R. A. \& YoO, A. L. (1969). Studies on a lipopolysaccharide from Escherichia coli. Heterogeneity and mechanism of reversible inactivation by sodium deoxycholate. Biochemistry 8, 4063-4067.

Mollaret, H. H. \& Nicolle, P. (1965). Sur la frequence de la lysogenie dans l'espece nouvelle Yersinia enterocolitica. Comptes rendus hebdomadaires des séances de l'Academie des sciences 260, 1027 1029.

NikAIDO, H. (1970). Structure of cell wall lipopolysaccharide from Salmonella typhimurium. Further studies on the linkage between O-side chains and R-core. European Journal of Biochemistry 15, 57-62.

Nowotny, A. (1966). Heterogeneity of endotoxic bacterial lipopolysaccharides revealed by ion-exchange column chromatography. Nature, London 210, 278-280.

OKamoto, K., Inoue, T., Ichikawa, H., Kamamoto, Y., HaRA, S. \& MiYama, A. (1980). Adherence of
Yersinia enterocolitica to mammalian epithelial cell lines. Microbiology and Immunology 24, 1013-1022.

PAI, C. H. \& MoRs, V. (1978). Production of enterotoxin by Yersinia enterocolitica. Infection and Immunity 19, 908-911.

Portnoy, D. A., Moseley, S. L. \& Falkow, S. (1981). Characterization of plasmid and plasmid associated determinants of Yersinia enterocolitica pathogenesis. Infection and Immunity 31, 775-782.

Schleifstein, J. \& Coleman, M. B. (1939). An identified microorganism resembling $B$. ligieresi and Pasteurella pseudotuberculosis, pathogenic for man. New York State Journal of Medicine 39, 1749-1753.

Straley, S. C. \& BRubaker, R. R. (1981). Cytoplasmic and membrane proteins of yersiniae cultivated under conditions simulating mammalian intracellular environment. Proceedings of the National Academy of Sciences of the United States of America 78 , $1224-1228$.

Straley, S. C. \& Brubaker, R. R. (1982). Localization in Yersinia pestis of peptides associated with virulence. Infection and Immunity 36, 129-135.

Tsubokura, M., Otsuki, K., ShimohiRa, I. \& YamaMOTO, H. (1979). Production of indirect hemolysin by Yersinia enterocolitica and its properties. Infection and Immunity 25, 939-942.

Tsuji, M., Kawaoka, Y., NaIKI, M. \& YanaGawa, R. (1981). Isolation of antigenically active components from leptospiral serovar-specific lipopolysaccharide antigen by alkaline treatment. Microbiology and Immunology 25, 949-957.

Weissbach, A. \& HuRwitz, J. (1959). The formation of 2-keto-3-deoxyheptonic acid in extracts of Escherichia coli B. I. Identification. Journal of Biological Chemistry 234, 705-709.

WESTPHAL, O. \& JANN, K. (1965). Bacterial lipopolysaccharide extraction with phenol-water and further application of the procedure. Methods in Carbohydrate Chemistry 5, 83-91.

Zahorchak, R. J., Charnetzky, W. T., Little, R. V. \& BRUBAKER, R. R. (1979). Consequences of $\mathrm{Ca}^{2+}$ deficiency on macromolecular synthesis and adenylate energy charge in Yersinia pestis. Journal of Bacteriology 139, 792-799. 